\title{
Two-way Fixed Effects Panel and Robustness Testing Model on Regional Economic Convergence
}

\author{
Bi Kewei ${ }^{1}$, Zhang Yanhua ${ }^{2,3}$ \\ ${ }^{1}$ Economics and Management School of Wuhan University, 430072, Wuhan, China \\ ${ }^{2}$ Hubei University of Technology School of economics and management , 430068, \\ Wuhan, China \\ ${ }^{3}$ Collaborative innovation center of regional industrial ecology development, \\ Hubei University of Technology, 430068, Wuhan,China. \\ 68363092@qq.com,zyhcqupt@163.com,
}

\begin{abstract}
Which functional mechanism will be more appropriate for regional economic growth in China's economy? this thesis conducts theoretical analysis concerned the functional mechanism conducts empirical test on the various effects of human capital based on the two-way fixed effects panel model and carries out robustness testing based on panel quantile regression. It is found that the direct effects of human capital outweigh its indirect effects with opposite signs, and it is mainly attributed to the poor matching of the technology introduced in the channel of domestic and international technology.
\end{abstract}

Keywords: regional economic convergence, Two-way fixed effects, robustness testing

\section{Introduction}

There have been abundant theories and assumptions about the effects of human capital on economic growth in the international research field. Nelson (2005) divided the relevant theories into two theoretical systems: accumulation theories and assimilation theories. Accumulation theories deal with the direct influences of human capital on economic growth, which involve the direct input of human capital into the production of end products as a factor of production and assume the contributory role of new human capital in economic growth. This is an exploration of the flow effect of human capital, with the empirical test generally based on the MRW (1992) growth regression framework. While assimilation theories is a theoretical mechanism where human capital exerts indirect effects on economic growth through total factor productivity or technological advances and they emphasize the indirect effects of human capital stock on economic growth, with the empirical tests generally based on the growth regression framework of Benhabib and Spiegel (1994). And the above two kinds of the functional mechanism of human capital can also be called growth effects and level effects (Dowrick, 2003). Besides, the internal mechanism of level effects can be further extended, that is, the influences on technological advances through innovation and technology spillover. And from the perspective of regional level, the source of technology spillover largely contain the source of domestic technology spillover and the source of international technology spillover (Kuo and Yang, 2008; Zhang and Sun, 2012). In addition, human capital can also affect economic growth indirectly through its complementarity with the physical capital.

So it can be found that human capital can influence economic growth through various and varied functional mechanisms. But for China's regional economy, which functional mechanism will be more appropriate to account for the facts of different regional economic growth in the current period? In response to this question, this thesis conducts theoretical analysis concerned the functional mechanism of human capital on regional 
economic growth. Through building a multiplicative interaction panel model, the thesis carries out empirical tests and compares the degrees of contribution of various effects to regional economic growth. The structure of the thesis is as follows: in the second part, the previous literature is briefly reviewed and a theoretical framework is delivered; in the third part, the multiplicative interaction panel econometric model is built based on growth convergence and regression framework; in the fourth part, the measuring and calculating methods as well as the sources of data for the variables will be demonstrated; in the fifth part, an empirical analysis is brought forth targeted at the various effects of human capital on economic growth and a robust test is also carried out on the basis of quantile regression and in the sixth part, the main conclusions are reached and presented and recommendations for policy are put forward for consideration.

\section{Literature Review}

In the theoretical field, the significance of human capital for sustainable economic development had been widely accepted (Schultz, 1961; Becker, 1964; Lucas, 1988; Romer, 1990; Aghion and Howitt, 1998). Mankiw, Romer and Weil (1992) made a pioneering work to introduce human capital into the Solow Model and made empirical tests on the theories and assumptions of the output effects of human capital. And they found the great contribution of human capital to economic growth. But Klenow, Rodrigue-Clare (1997) and Bils, Klenow (2000) likewise regarded human capital as a kind of factor of production and chose different measuring indicators of human capital for empirical test on the basis of considering the potential measuring error. And they eventually found that the contribution of the investment in human capital to economic growth had prominently declined. Pritchett (2001) also found evidence that the expansion of education cannot lead to economic growth. But the above studies pay more attention to the direct influences of human capital, without taking into account the indirect effects of human capital on economic growth, so the conclusions they arrived might have underestimated the contribution of human capital to economic growth.

In the internal theoretical field, theories and mechanisms about the indirect effects of human capital on economic growth generally highlight technological advances through which human capital affect economic development indirectly. And the theories can be classified into two categories: one is the theories put forward by Romer (1990), and Aghion and Howitt (1998) that human capital can promote innovation and improve the rate of technological advances and thus affect economic growth indirectly. And the other is put forward by Nelson and Phelps (1966), who proposed that technologically backward countries can strengthen their abilities of technology absorption through accumulation of human capital and can thus digest and absorb the introduced technology in a relatively quick way and improve the rate of technological progress. In this way, the economic growth is stimulated. While Benhabb and Spiegel $(1994,2005)$ argue that the above two ways of human capital exerting its influences are complementary. And they integrated the two into a framework of empirical model and compared it with the estimation results of the traditional neo-classic econometric model. They finally found that after considering the indirect influences human capital on economic development, the overall effects of human capital no economic growth is more prominent. Besides, a great proportion of scholars also pay attention to the role of human capital in various channels of technology spillover. From the angle of the source of technology spillover, Keller (1996), Borensztein et al (1998), Xu (2000), Acharya and Keller (2009) discovered that when the level of human capital reaches a certain degree, it will be beneficial to import trade and the functioning of the FDI technology spillover effects and thus promote economic growth indirectly. In addition to the above literature, Berman et al (2005) explained the indirect influences of human capital on economic growth from the complementarity of physical capital with human capital. They revealed that on the assumed premise of 
technique-inclined technological progress hypothesis, human capital level will promote the accumulation of physical capital and realize the deepening of capital to promote economic growth.

In summary, a relatively comprehensive and systematic empirical analysis is absent to study the mechanism of the influences of human capital on China's regional economic growth and its discrepancies. Is there consistency between the aggregate effects of human capital in different regions? Is the status of various subordinate effects in various regions different? If it is, then is there a necessary link between the differences and the discrepancies of regional economic growth? No scholars have given empirically comprehensive answer to these questions till now. On the basis of comprehensively analyzing the internal mechanism of the four main effects of human capital, this thesis thus build the multiplicative interaction panel model and conduct empirical test on the various human capital effects between 1987 and 2014, to judge the status of human capital in China's regional economic development in a relatively accurate way.

\section{Model}

This thesis build the multiplicative interaction dynamic panel models (1) to investigate the various effects through which human capital affect China's regional economic development and their differences. In the models, human capital (h) is viewed as a way to improve the labor quality and the potential cardinal number of labors available for training (Zhang, 2000). It has direct influence on economic growth, namely the output effects and innovation effects. This variablelag 2 or 3 has taken into full consideration the delayed functioning of learning by doing effects and the interaction terms coefficient of human capital (h) and physical capital (I) studies the complementary effects of human capital.And the absorption effect of human capital on the various channels of technology spillover is considered through its interactions terms with the domestic regional technology diffusion $\left(\mathrm{STFP}_{\mathrm{it}}\right)$, import trade channel led technology spillover $\left(\mathrm{IMP}_{\mathrm{it}}\right)$ and foreign direct investment led technology spillover $\left(\mathrm{FDI}_{\mathrm{it}}\right)$ respectively. And in the following formula, the subscript of the variables $i, t$ and $j$ refers to the $i$ province, the $t$ year and lag $\mathrm{j}$ respectively. And it is notable that the following models study the human capital effects from the aggregate angle.Due to great differences of regions in distance with domestic technology and with international technology, and differences in the settings of technology barrier, spatial distance and other aspects, the functioning of international technology spillover requires longer period compared with that of the domestic technology spillover effect, which means there is a lagged effect, for example, it will take certain time to absorb, imitate and learn the technology introduced or spilled over through FDI. So there exists a lagged effect on the change of total factor productivity. And based on the different degree of difficult needed for absorption, the thesis thus lags the FDI by 1 , and lags the IMP by 2 respectively so as to study the international technology spillover effect accurately. And the other variable I refers to the investment of the quantity of labor force, while the individual effect $\mu_{\mathrm{i}}$ and time effect $\gamma_{\mathrm{t}}$ are considered at the same time to solve the problem of the heterogeneity of samples.

$$
\begin{aligned}
\Delta \ln y_{i t}= & c+\mu_{i}+\lambda_{t}+\alpha \ln y_{i t-1}+\sum_{j} \beta_{h}^{j} \ln h_{i t-j}+\beta_{I}^{1} \ln I_{i t}+\beta_{I}^{2} \ln I_{i t} \ln h_{i t}+\beta_{f d i}^{1} F D I_{i t-1} \\
& +\beta_{f d i}^{2} F D I_{i t-1} \log h_{i t-1}+\beta_{i m}^{1} I M P_{i t-2}+\beta_{i m}^{2} I M P_{i t-2} \log h_{i t-2}+\beta_{s}^{1} S T F P_{i t} \\
& +\beta_{s}^{2} S T F P_{i t} \log h_{i t}+\beta_{L} \Delta \log L_{i t}+\Delta \varepsilon_{i, t}
\end{aligned}
$$

Based on the above empirical model, it is notable that if technological progress is viewed as the external sign of regional economic development, then the innovation effect of human capital can also be seen as a kind of directly influencing mechanism and in the model, it is integrated with the direct output effects to be combined and called the direct effects of human capital. The detailed measuring methods and data processing of variables are demonstrated below: 
(1) Per capita GDP and growth rate of per capita GDP.The thesis uses the per capita real GDP from 1987 to 2014 to represent the average per capita income and the data in 1978 is chosen as the base period. Real GDP is produced based on the GDP index of various provinces, and when it is divided by the total number of the local employed person, the per capita real GDP is made and the growth rate of per capita real GDP in various provinces is thus further calculated.

(2) Human capital level. This thesis refers to the study of Barro and Lee (1993) to use the regional per capita educational years as the proxy variable for the human capital level.The detailed formula is $H_{t}=\sum_{i}\left(H E_{i t} * h_{i}\right) . \mathrm{H}_{\mathrm{t}}$ refers to the human capital stock in phase $\mathrm{t}, \mathrm{HE}_{\mathrm{t}}$ refers to the proportion of labor force in the i degree of education in phase $\mathrm{t}$, $\mathrm{h}_{\mathrm{i}}$ refers to the educational year of people in the i degree of education.

(3) The international technology spillover of FDI and import trade. The channels of international technology spillover mainly include that of FDI and import trade (Coe and Helpman, 1995) and they both can provide advanced technology and sophisticated management expertise for the opening up regions.

(4) Actual input of physical capital.This thesis imitates the handling method of Zhang Jun (2004) to measure and calculate the real stock of the physical capital of the 28 provinces during 1987 and 2014 (with the data of 1978 as the base period), which means indicators for the investment volume in the current period adopt the gross fixed capital formation and make use of the price indices investment in fixed assets to convert into the gross fixed capital formation with the prices in 1978 as the benchmark.

(5) Domestic technology diffusion term. The domestic technology diffusion mainly means that the developed regions can diffuse the lead-edge technologies to the less developed regions through methods such as merchandise trade, flow of factor of production and technical assistance and etc. Therefore, the domestic technology diffusion term can be expressed as:

$$
S T F P_{i t}=\sum_{j=1, j \neq i}^{n}\left(t p f_{j t} / d_{i j}^{2}\right)
$$

In this formula, $\mathrm{d}_{\mathrm{ij}}$ refers to the spherical distance of the capital cities of the two provinces $\mathrm{j}$ and $\mathrm{i}$, and $\mathrm{tpf}_{\mathrm{jt}}$ refers to total factor productivity of province $\mathrm{j}$ in the $\mathrm{t}$ period.

\section{Two-way Fixed Effect Analysis}

The sample period chosen in the thesis is from 1987 to 2014 and since for some variables, the data of Chongqing, Hainan Province and Xizang Autonomous Region is in serious shortage, Chungking is combined with Sichuan Province, Hainan Province with Guangdong Province and Xizang Autonomous Region is excluded in the research. And Hong Kong, Macao and Taiwan, being greatly different with the other parts of China in institutions and background, are also excluded in the samples.

The FGLS estimation method is adopted to estimate the two-way fixed effect panel model, for example, in the fixed effect test in pattern (1) - (6) in Table 1-2 below, when considering the heteroscedasticity, the Wald test statistics all reject the random effect in a prominent way under the level of $1 \%$, which proves the reasonability of the setting of two-way fixed effect panel model. And the intra-group autocorrelation test shows that the Wald test statistics all, under the level of $1 \%$, reject in a prominent way the null hypothesis that there is absolute no first-order intra-group autocorrelation. And the test results of Pesaran, Fridman and Fress all reject in a prominent way under the level of $1 \%$ the null hypothesis that there is no cross sectional correlation. This also justifies the 
necessity of adopting FGLS for estimation. In general, the result of the model simulation is generally good and the conspicuousness of various parameters is all in good condition.

Table 1. Two-way Fixed Effect Model on Econometric Result

\begin{tabular}{|c|c|c|c|c|c|c|}
\hline \multirow{2}{*}{$\begin{array}{c}\text { Dependent Variable } \\
\Delta \ln y_{\mathrm{t}}\end{array}$} & \multicolumn{6}{|c|}{ Two-way Fixed Effect Model (FGLS estimation) } \\
\hline & (1) & (2) & (3) & (4) & (5) & (6) \\
\hline $\operatorname{lny}_{t-1}$ & $\begin{array}{l}-0.2520 * * * \\
(0.0034)\end{array}$ & $\begin{array}{l}-0.2220 * * * \\
(0.0066)\end{array}$ & $\begin{array}{l}-0.2520 * * * \\
(0.0053)\end{array}$ & $\begin{array}{l}-0.2210 * * * \\
(0.0068)\end{array}$ & $\begin{array}{l}-0.2050 * * * \\
(0.0056)\end{array}$ & $\begin{array}{l}-0.2130 * * * \\
(0.0052)\end{array}$ \\
\hline $\ln I_{t}$ & $\begin{array}{l}0.2530 * * * \\
(0.0027)\end{array}$ & $\begin{array}{l}0.2280 * * * \\
(0.0060)\end{array}$ & $\begin{array}{l}0.2150 * * * \\
(0.0045)\end{array}$ & $\begin{array}{l}0.2330 * * * \\
(0.0068)\end{array}$ & $\begin{array}{l}0.2220 * * * \\
(0.0053)\end{array}$ & $\begin{array}{l}0.1960 * * * \\
(0.0084)\end{array}$ \\
\hline $\operatorname{lnh}$ & $\begin{array}{l}-0.0162 * * * \\
(0.00212)\end{array}$ & $\begin{array}{l}-0.0273 * * * \\
(0.00589)\end{array}$ & $\begin{array}{l}-0.0258 * * \\
(0.0116)\end{array}$ & $\begin{array}{l}-0.0229 * * * \\
(0.00486)\end{array}$ & $\begin{array}{l}0.0301 * * * \\
(0.00632)\end{array}$ & $\begin{array}{l}-0.0413 * * \\
(0.0185)\end{array}$ \\
\hline $\operatorname{Lnh}_{t-1}$ & & $\begin{array}{l}-0.0024 \\
(0.0065)\end{array}$ & $\begin{array}{l}0.0148 * * * \\
(0.0053)\end{array}$ & $\begin{array}{l}-0.00131 \\
(0.0047)\end{array}$ & $\begin{array}{l}0.0018 \\
(0.0065)\end{array}$ & $\begin{array}{l}0.0285 * * * \\
(0.0057)\end{array}$ \\
\hline $\operatorname{Lnh}_{\mathrm{t}-2}$ & & $\begin{array}{l}0.0203 * * * \\
(0.0064)\end{array}$ & $\begin{array}{l}0.0221 * * * \\
(0.0049)\end{array}$ & $\begin{array}{l}0.0163 * * * \\
(0.0048)\end{array}$ & $\begin{array}{l}0.0471 * * * \\
(0.0057)\end{array}$ & $\begin{array}{l}0.0596 * * * \\
(0.0056)\end{array}$ \\
\hline $\operatorname{Lnh}_{\mathrm{t}-3}$ & & $\begin{array}{l}0.0445 * * * \\
(0.0053)\end{array}$ & & $\begin{array}{l}0.0345 * * * \\
(0.0045)\end{array}$ & & \\
\hline $\mathrm{stfp}_{\mathrm{t}}$ & & & & $\begin{array}{l}0.00160 * * * \\
(0.0002)\end{array}$ & $\begin{array}{l}0.00885 * * * \\
(0.0005)\end{array}$ & $\begin{array}{l}0.0100 * * * \\
(0.0006)\end{array}$ \\
\hline $\mathrm{fdi}_{\mathrm{t}-1}$ & & & & $\begin{array}{l}0.00486 * * * \\
(0.00077)\end{array}$ & $\begin{array}{l}0.0103 * \\
(0.0054)\end{array}$ & $\begin{array}{l}0.0298 * * * \\
(0.0054)\end{array}$ \\
\hline import $_{\mathrm{t}-2}$ & & & & $\begin{array}{l}0.00712 * * * \\
(0.0006)\end{array}$ & $\begin{array}{l}0.122 * * * \\
(0.0041)\end{array}$ & $\begin{array}{l}0.132 * * * \\
(0.0056)\end{array}$ \\
\hline $\ln I_{t} * \operatorname{lnh}_{t}$ & & & $\begin{array}{l}0.0066 * * * \\
(0.0016)\end{array}$ & & & $\begin{array}{l}0.0163 * * * \\
(0.0027)\end{array}$ \\
\hline $\operatorname{stfp}_{\mathrm{t}} * \operatorname{lnh}_{\mathrm{t}}$ & & & & & $\begin{array}{l}-0.0024 * * * \\
(0.0002)\end{array}$ & $\begin{array}{l}-0.0030 * * * \\
(0.0003)\end{array}$ \\
\hline $\mathrm{fdi}_{\mathrm{t}-1} * \operatorname{lnh}_{\mathrm{t}-1}$ & & & & & $\begin{array}{l}-0.0065 * * \\
(0.0027)\end{array}$ & $\begin{array}{l}-0.0162 * * * \\
(0.0026)\end{array}$ \\
\hline $\operatorname{import}_{\mathrm{t}-2} * \operatorname{lnh}_{\mathrm{t}-2}$ & & & & & $\begin{array}{l}-0.0558 * * * \\
(0.0020)\end{array}$ & $\begin{array}{l}-0.0611 * * * \\
(0.0027)\end{array}$ \\
\hline$\Delta \operatorname{lnL} \mathrm{L}_{\mathrm{it}}$ & $\begin{array}{l}-0.836 * * * \\
(0.0030)\end{array}$ & $\begin{array}{l}-0.836 * * * \\
(0.0064)\end{array}$ & $\begin{array}{l}-0.835 * * * \\
(0.0050)\end{array}$ & $\begin{array}{l}-0.843 * * * \\
(0.0061)\end{array}$ & $\begin{array}{l}-0.860 * * * \\
(0.0060)\end{array}$ & $\begin{array}{l}-0.856 * * * \\
(0.0053)\end{array}$ \\
\hline $\mathrm{t}$ & $\begin{array}{l}-0.0032 * * * \\
(0.0002)\end{array}$ & $\begin{array}{l}-0.0046 * * * \\
(0.0006)\end{array}$ & $\begin{array}{l}-0.0026^{* * * *} \\
(0.0004)\end{array}$ & $\begin{array}{l}-0.0052 * * * \\
(0.0005)\end{array}$ & $\begin{array}{l}-0.0044 * * * \\
(0.0005)\end{array}$ & $\begin{array}{l}-0.0055^{* * * *} \\
(0.0005)\end{array}$ \\
\hline Constant & $\begin{array}{l}1.052^{* * *} \\
(0.0267)\end{array}$ & $\begin{array}{l}4.205^{* * *} \\
(0.913)\end{array}$ & $\begin{array}{l}1.549 * * * \\
(0.0878)\end{array}$ & $\begin{array}{l}0.605 * * * \\
(0.0430)\end{array}$ & $\begin{array}{l}0.338 * * * \\
(0.0477)\end{array}$ & $\begin{array}{l}0.433 * * * \\
(0.0586)\end{array}$ \\
\hline Observed Value & 588 & 532 & 560 & 532 & 560 & 560 \\
\hline Adjusted $\mathrm{R}^{2}$ & 0.715 & 0.763 & 0.731 & 0.779 & 0.795 & 0.796 \\
\hline Fixed Effect Test & $39.76 * * *$ & $359.09 * * *$ & $233.56^{* * *}$ & $254.58 * * *$ & $543.87 * * *$ & $783.76 * * *$ \\
\hline Autocorrelation Test & $103.4 * * *$ & $168.1 * * *$ & $140.8 * * *$ & $224.5 * * *$ & $187.9 * * *$ & $175.2 * * *$ \\
\hline Cross-sectional Fress & $4.449 * * *$ & $3.767 * * *$ & $4.634 * * *$ & $3.589 * * *$ & $3.683 * * *$ & $3.55^{* * *} *$ \\
\hline Correlation Pesaran & $28.98 * * *$ & $22.54 * * *$ & $27.47 * * *$ & $22.73 * * *$ & $22.45 * * *$ & $21.493 * * *$ \\
\hline Friedman & $187.94 * * *$ & $161.78 * * *$ & $189.5^{* * *}$ & $156.8 * * *$ & $164.94 * * *$ & $162.2 * * *$ \\
\hline
\end{tabular}

Notes: (1) $* * *, * *, *$ refers to the significance at the level of $1 \%, 5 \%$, and $10 \%$ respectively; (2) data within the bracket is the robust standard error.

In Table 1 , it is found that the significance of the influential coefficient of human capital level is negative, which means the change of human capital level is not beneficial to the growth rate of per capita output. This conclusion is just the opposite with the neo-classical and the new growth economic theory and is consistent with the research results of the majority scholars from the domestic and international academic field.So it is believed that the output effect of human capital have certain lagged effect. For this purpose, the pattern (2) in Table 3 is established and the direct output effect of human capital from the current phase to three phases lagged is respectively $-0.0273,-0.0024$, 0.0203 and 0.0445 , presenting a tendency of gradual increase and the long-term effect or total effect is 0.0351 , while the output effect of physical capital investment decreased to 0.2280 from the original 0.2530 . 
Table 2. Econometric Results of Human Capital Effects on Different Regional Level

\begin{tabular}{|c|c|c|c|c|c|c|c|}
\hline \multirow{3}{*}{$\begin{array}{c}\text { Dependent } \\
\text { Variable } \\
\Delta \ln y_{\mathrm{t}}\end{array}$} & \multirow[t]{2}{*}{ Eastern } & \multirow{2}{*}{$\begin{array}{c}\text { Non-easter } \\
\mathrm{n}\end{array}$} & \multicolumn{3}{|c|}{$\begin{array}{c}\text { Regions for Implementing the } \\
\text { Strategy of Coordinated Regional } \\
\text { Development }\end{array}$} & \multirow{2}{*}{$\begin{array}{l}\text { Coastal } \\
\text { Regions }\end{array}$} & \multirow[t]{3}{*}{ Inland } \\
\hline & & & Western & Middle & Northeaster & & \\
\hline & (1) & (2) & (3) & (4) & (5) & (6) & \\
\hline \multirow[t]{2}{*}{$\operatorname{lny}_{\mathrm{t}-1}$} & $-0.150 * * *$ & $-0.241 * * *$ & $-0.188 * * *$ & $-0.392 * * *$ & $-0.234 * * *$ & $-0.171 * * *$ & $-0.262 * * *$ \\
\hline & $(0.0150)$ & $(0.0045)$ & $(0.0138)$ & $(0.0350)$ & $(0.0406)$ & $(0.0112)$ & $(0.0083)$ \\
\hline \multirow[t]{2}{*}{$\ln I_{t}$} & $0.176^{* * *}$ & $0.157 * * *$ & $0.101 * * *$ & $0.293 * * *$ & $0.225 * * *$ & $0.157 * * *$ & $0.169 * * *$ \\
\hline & $(0.0326)$ & $(0.0054)$ & $(0.0211)$ & $(0.0744)$ & $(0.0643)$ & $(0.0230)$ & $(0.0088)$ \\
\hline \multirow[t]{2}{*}{$\operatorname{lnh}$} & -0.132 & $-0.145 * * *$ & $-0.256 * * *$ & 0.002 & -0.200 & -0.068 & $-0.149 * * *$ \\
\hline & $(0.0931)$ & $(0.0138)$ & $(0.0565)$ & $(0.0320)$ & $(0.4220)$ & $(0.0629)$ & $(0.0192)$ \\
\hline \multirow[t]{2}{*}{$\operatorname{lnh}_{\mathrm{t}-1}$} & -0.0117 & $0.0401 * * *$ & $0.0256^{*}$ & 0.0479 & 0.0315 & $-0.0483 * * *$ & $0.0439 * * *$ \\
\hline & $(0.0228)$ & $(0.0040)$ & $(0.0154)$ & $(0.0338)$ & $(0.0945)$ & $(0.0187)$ & $(0.0074)$ \\
\hline \multirow[t]{2}{*}{$\operatorname{lnh}_{\mathrm{t}-2}$} & $\begin{array}{c}0.0935^{* *} \\
*\end{array}$ & $0.0650 * * *$ & $\begin{array}{c}0.0720^{* *} \\
*\end{array}$ & $0.0775 * *$ & 0.0391 & $0.0760 * * *$ & $0.0688 * * *$ \\
\hline & $(0.0206)$ & $(0.0041)$ & $(0.0146)$ & $(0.0353)$ & $(0.0984)$ & $(0.0172)$ & $(0.0071)$ \\
\hline \multirow[t]{2}{*}{$\mathrm{sftp}_{\mathrm{t}}$} & $0.0034 * *$ & $0.0080 * * *$ & $-0.0123 * *$ & $0.0148 * *$ & $-0.0793 * *$ & $\begin{array}{c}0.00886^{* *} \\
*\end{array}$ & $0.00558 * *$ \\
\hline & $(0.0017)$ & $(0.0015)$ & $(0.0060)$ & $(0.0067)$ & $(0.0380)$ & $(0.0012)$ & $(0.0022)$ \\
\hline \multirow[t]{2}{*}{$\mathrm{fdi}_{\mathrm{t}-1}$} & $0.0256 *$ & $0.0306^{* * *}$ & 0.0680 & $-0.1660 * *$ & $-0.0079 *$ & $0.0255 * *$ & 0.0243 \\
\hline & $(0.0131)$ & (0.0104) & $(0.0492)$ & $(0.0678)$ & $(0.00473)$ & $(0.0120)$ & $(0.0219)$ \\
\hline $\operatorname{import}_{t-2}$ & $\begin{array}{c}0.0913 * * \\
*\end{array}$ & $0.2070 * * *$ & $0.0828 *$ & $\begin{array}{c}0.5060 * * \\
*\end{array}$ & $0.0197 * * *$ & $0.1340 * * *$ & $0.1760 * * *$ \\
\hline \multirow{3}{*}{$\ln \mathrm{I}_{\mathrm{t}} * \operatorname{lnh}_{\mathrm{t}}$} & $(0.0150)$ & $(0.0129)$ & $(0.0425)$ & $(0.1600)$ & $(0.0071)$ & (0.0109) & $(0.0203)$ \\
\hline & 0.0169 & $0.0349 * * *$ & $\begin{array}{c}0.0418 * * \\
*\end{array}$ & $0.0170^{*}$ & 0.00281 & 0.00865 & $0.0359 * * *$ \\
\hline & $(0.0127)$ & $(0.0018)$ & $(0.0068)$ & $(0.0087)$ & $(0.0583)$ & $(0.0085)$ & $(0.0027)$ \\
\hline \multirow[t]{2}{*}{$\operatorname{stfp}_{t} * \operatorname{lnh}_{t}$} & -0.0010 & $-0.0030 * * *$ & $0.0080 * *$ & $-0.0060 *$ & $0.0370 * *$ & $-0.0020 * * *$ & $-0.0020 *$ \\
\hline & $(0.0006)$ & $(0.0007)$ & $(0.00349)$ & $(0.0031)$ & $(0.0184)$ & $(0.0005)$ & $(0.0010)$ \\
\hline \multirow{2}{*}{$\mathrm{fdi}_{\mathrm{t}-1} * \operatorname{lnh}_{\mathrm{t}-1}$} & $-0.0147 * *$ & $-0.0172 * * *$ & -0.0370 & $0.0792 * *$ & 0.0324 & $-0.0135^{* *}$ & -0.0141 \\
\hline & $(0.0065)$ & $(0.0052)$ & $(0.0256)$ & $(0.0329)$ & $(0.0515)$ & $(0.0059)$ & $(0.0113)$ \\
\hline \multirow[t]{2}{*}{$\operatorname{import}_{\mathrm{t}-2} * \operatorname{lnh}_{\mathrm{t}-2}$} & $-0.041 * * *$ & $-0.1030 * * *$ & $-0.0436 *$ & $-0.2420 * *$ & -0.0505 & $-0.0625 * * *$ & $\begin{array}{c}-0.0890 * * \\
*\end{array}$ \\
\hline & $(0.00740)$ & $(0.00659)$ & $(0.0223)$ & $(0.0831)$ & $(0.0694)$ & $(0.0054)$ & $(0.0107)$ \\
\hline \multirow[t]{2}{*}{$\Delta \operatorname{lnL} L_{t}$} & $-0.895 * * *$ & $-0.838 * * *$ & $-0.869 * * *$ & $-0.781 * *$ & $-0.839 * * *$ & $-0.884 * * *$ & $-0.832 * * *$ \\
\hline & $(0.0137)$ & $(0.00515)$ & $(0.0200)$ & $(0.0362)$ & $(0.0345)$ & $(0.0103)$ & $(0.0116)$ \\
\hline \multirow[t]{2}{*}{$\mathrm{t}$} & $-0.010 * * *$ & $-0.003 * * *$ & $-0.0020 * *$ & $0.00492 *$ & 0.00489 & $-0.003 * * *$ & $-0.003 * * *$ \\
\hline & $(0.0022)$ & $(0.0004)$ & $(0.0013)$ & $(0.0029)$ & $(0.0046)$ & $(0.0010)$ & $(0.0007)$ \\
\hline \multirow{3}{*}{$\begin{array}{l}\text { Observed Value } \\
\text { Adjusted } \mathrm{R}^{2} \\
\text { Fixed Effect Test }\end{array}$} & 180 & 380 & 200 & 120 & 60 & 240 & 240 \\
\hline & 0.86 & 0.755 & 0.814 & 0.759 & 0.924 & 0.841 & 0.761 \\
\hline & $22033 * * *$ & $235.52 * * *$ & $16952 * * *$ & $215.3^{* * *}$ & $828.5 * * *$ & $\begin{array}{c}9.8 \mathrm{e}+05 * * \\
*\end{array}$ & $1115.3^{* *}$ \\
\hline $\begin{array}{l}\text { Autocorrelation } \\
\text { test }\end{array}$ & $190.5 * * *$ & $180.74 * * *$ & $66.03 * * *$ & $94.04 * * *$ & $398.9 * * *$ & $108.49 * * *$ & $176.5 * * *$ \\
\hline \multirow{3}{*}{$\begin{array}{c}\text { CSC } \\
\mathrm{T}\end{array}$} & $1.82 * * *$ & $1.42 * * *$ & $0.45^{* * *}$ & $0.73 * * *$ & $0.27 * * *$ & $1.57 * * *$ & $1.29 * * *$ \\
\hline & $8.52 * * *$ & $11.35 * * *$ & $3.94 * * *$ & $4.03 * * *$ & $13.02 * * *$ & $8.21 * * *$ & $9.84 * * *$ \\
\hline & $71.52 * * *$ & $97.85 * * *$ & $42.17 * * *$ & $47.84 * * *$ & $10.87 * * *$ & $73.55 * * *$ & $84.77 * * *$ \\
\hline
\end{tabular}

Notes: (1) ***, **, * refers to the significance at the level of $1 \%, 5 \%$, and $10 \%$ respectively; (2) data within the bracket is the robust standard error. (3) CSCT(Cross sectional correlation test)

For convenient comparison, the patterns (3) - (5) of the model in Table 1 are established for analysis one by one. The pattern (3) in Table 2 shows that the coefficient of the complementary effect of human capital presents a significant positive influence and the output effect of human capital can work one phase ahead of time. Based on the economic connotation of the coefficient of interaction terms, the coefficient of complementary effect is a positive sign.

As is presented in model (6) of Table 1, it is found that the lagged effect of human capital still appear to be gradually increasing, which fully demonstrates the importance of 
learning by doping effect for economic growth. And it is far higher than the direct effect of human capital in model (2) -model (4), reaching 0.0468

\section{Robustness Testing}

All conclusions above are made on the premise of the unique equilibrium hypothesis, but generally economists have fully proven the existence of multiple equilibriums from both theoretical and empirical aspects. So on the basis of the quantile regression method and the estimation multiplicative interaction two-way fixed effect model, this thesis will study whether there is a big difference of human capital effect in regions of high growth rate and regions of low growth rate. And the results are compared with above conclusions to test the robustness of the main conclusions of the thesis. The estimation results are shown in Table 3 below.

Table 3. Quantile Regression Results of the Two-way Fixed Effect Panel

\begin{tabular}{|c|c|c|c|c|c|c|c|}
\hline $\begin{array}{l}\text { Dependent } \\
\text { Variable }\end{array}$ & (1) & (2) & (3) & (4) & (5) & (6) & (7) \\
\hline$\Delta \ln y_{t}$ & $\mathrm{q} 20$ & $\mathrm{q} 30$ & $\mathrm{q} 40$ & $\mathrm{q} 50$ & $\mathrm{q} 60$ & q70 & q80 \\
\hline $\ln y_{t-1}$ & $\begin{array}{c}-0.142 * * * \\
(0.0222)\end{array}$ & $\begin{array}{c}-0.130 * * * \\
(0.0197)\end{array}$ & $\begin{array}{c}-0.131 * * * \\
(0.0181)\end{array}$ & $\begin{array}{c}-0.130 * * * \\
(0.0174)\end{array}$ & $\begin{array}{c}-0.138 * * * \\
(0.0180)\end{array}$ & $\begin{array}{c}-0.134 * * * \\
(0.0201)\end{array}$ & $\begin{array}{c}-0.153 * * * \\
(0.0231)\end{array}$ \\
\hline $\ln I_{t}$ & $\begin{array}{c}0.132 * * * \\
(0.0234)\end{array}$ & $\begin{array}{c}0.144 * * * \\
(0.0209)\end{array}$ & $\begin{array}{c}0.142 * * * \\
(0.0194)\end{array}$ & $\begin{array}{c}0.139 * * * \\
(0.0187)\end{array}$ & $\begin{array}{c}0.143 * * * \\
(0.0185)\end{array}$ & $\begin{array}{c}0.155 * * * \\
(0.0209)\end{array}$ & $\begin{array}{c}0.169 * * * \\
(0.0236)\end{array}$ \\
\hline $\operatorname{lnh}_{t-2}$ & $\begin{array}{c}0.0989 * * \\
(0.0418)\end{array}$ & $\begin{array}{c}0.104 * * * \\
(0.0348)\end{array}$ & $\begin{array}{c}0.0951 * * * \\
(0.0300)\end{array}$ & $\begin{array}{c}0.107 * * * \\
(0.0296)\end{array}$ & $\begin{array}{c}0.0960 * * * \\
(0.0283)\end{array}$ & $\begin{array}{c}0.0906 * * * \\
(0.0280)\end{array}$ & $\begin{array}{c}0.0744 * * * \\
(0.0280)\end{array}$ \\
\hline $\mathrm{sftp}_{\mathrm{t}}$ & $\begin{array}{c}0.0102 * * * \\
(0.00279)\end{array}$ & $\begin{array}{c}0.0105 * * * \\
(0.00299)\end{array}$ & $\begin{array}{c}0.00848^{* * * *} \\
(0.00323)\end{array}$ & $\begin{array}{c}0.00803 * * \\
(0.00323)\end{array}$ & $\begin{array}{c}0.00848^{* *} \\
(0.00355)\end{array}$ & $\begin{array}{l}0.0101 * * \\
(0.00402)\end{array}$ & $\begin{array}{c}0.0132 * * * \\
(0.00430)\end{array}$ \\
\hline $\mathrm{fdi}_{\mathrm{t}-1}$ & $\begin{array}{l}-0.0556 \\
(0.0457)\end{array}$ & $\begin{array}{c}-0.0477 \\
(0.0429)\end{array}$ & $\begin{array}{c}-0.0193 \\
(0.0427)\end{array}$ & $\begin{array}{l}-0.0217 \\
(0.0416)\end{array}$ & $\begin{array}{c}-0.0294 \\
(0.0421)\end{array}$ & $\begin{array}{c}-0.0282 \\
(0.0477)\end{array}$ & $\begin{array}{l}-0.0384 \\
(0.0530)\end{array}$ \\
\hline import $_{t-2}$ & $\begin{array}{c}0.206 * * * \\
(0.0306)\end{array}$ & $\begin{array}{c}0.182 * * * \\
(0.0303)\end{array}$ & $\begin{array}{c}0.177 * * * \\
(0.0279)\end{array}$ & $\begin{array}{r}0.157 * * * \\
(0.0278)\end{array}$ & $\begin{array}{c}0.147 * * * \\
(0.0288)\end{array}$ & $\begin{array}{r}0.135 * * * \\
(0.0322)\end{array}$ & $\begin{array}{c}0.116 * * * \\
(0.0366)\end{array}$ \\
\hline $\ln \mathrm{I}_{\mathrm{t}} * \operatorname{lnh}_{\mathrm{t}}$ & $\begin{array}{c}0.0123 \\
(0.0108)\end{array}$ & $\begin{array}{c}0.0100 \\
(0.0102)\end{array}$ & $\begin{array}{c}0.0111 \\
(0.00923)\end{array}$ & $\begin{array}{c}0.00785 \\
(0.00843)\end{array}$ & $\begin{array}{c}0.00891 \\
(0.00871)\end{array}$ & $\begin{array}{c}0.00809 \\
(0.00896)\end{array}$ & $\begin{array}{c}0.00774 \\
(0.00993)\end{array}$ \\
\hline $\operatorname{stfp}_{\mathrm{t}} * \operatorname{lnh}_{\mathrm{t}}$ & $\begin{array}{c}-0.0028 * * \\
(0.00119)\end{array}$ & $\begin{array}{c}-0.0031 * * * \\
(0.00118)\end{array}$ & $\begin{array}{c}-0.0032 * * \\
(0.00126)\end{array}$ & $\begin{array}{c}-0.0029 * * \\
(0.00130)\end{array}$ & $\begin{array}{l}-0.0033 * * \\
(0.00148)\end{array}$ & $\begin{array}{l}-0.0030 * \\
(0.00173)\end{array}$ & $\begin{array}{l}-0.0046^{* *} \\
(0.00189)\end{array}$ \\
\hline $\mathrm{fdi}_{\mathrm{t}-1} * \operatorname{lnh}_{\mathrm{t}-1}$ & $\begin{array}{c}0.0253 \\
(0.0224)\end{array}$ & $\begin{array}{c}0.0213 \\
(0.0210)\end{array}$ & $\begin{array}{l}0.00736 \\
(0.0211)\end{array}$ & $\begin{array}{l}0.00944 \\
(0.0205)\end{array}$ & $\begin{array}{c}0.0129 \\
(0.0207)\end{array}$ & $\begin{array}{c}0.0126 \\
(0.0232)\end{array}$ & $\begin{array}{c}0.0185 \\
(0.0258)\end{array}$ \\
\hline $\operatorname{import}_{\mathrm{t}-2} *$ & $-0.0983 * * *$ & $-0.0866 * * *$ & $-0.0843 * * *$ & $-0.0738 * * *$ & $\begin{array}{c}-0.0693 * * * \\
(0.0141)\end{array}$ & $-0.0648 * * *$ & $\begin{array}{c}-0.0541 * * * \\
(0.0178)\end{array}$ \\
\hline$\Delta \ln L_{t}$ & $\begin{array}{c}-0.864 * * * \\
(0.0362)\end{array}$ & $\begin{array}{c}-0.882 * * * \\
(0.0339)\end{array}$ & $\begin{array}{c}-0.866^{* * * *} \\
(0.0319)\end{array}$ & $\begin{array}{c}-0.853 * * * \\
(0.0318)\end{array}$ & $\begin{array}{c}-0.859 * * * \\
(0.0336)\end{array}$ & $\begin{array}{c}-0.889 * * * \\
(0.0339)\end{array}$ & $\begin{array}{c}-0.900 * * * \\
(0.0356)\end{array}$ \\
\hline $\mathrm{t}$ & $\begin{array}{c}-0.0024 \\
(0.00171)\end{array}$ & $\begin{array}{c}-0.0044 * * * \\
(0.00168)\end{array}$ & $\begin{array}{c}-0.0047 * * * \\
(0.00165)\end{array}$ & $\begin{array}{c}-0.0032 * * \\
(0.00162)\end{array}$ & $\begin{array}{c}-0.0034 * * \\
(0.00166)\end{array}$ & $\begin{array}{c}-0.0051 * * * \\
(0.00181)\end{array}$ & $\begin{array}{l}-0.0045^{* *} \\
(0.00198)\end{array}$ \\
\hline Constant & $\begin{array}{c}0.141 \\
(0.209) \\
\end{array}$ & $\begin{array}{l}0.0166 \\
(0.216) \\
\end{array}$ & $\begin{array}{c}0.146 \\
(0.223) \\
\end{array}$ & $\begin{array}{c}0.262 \\
(0.229) \\
\end{array}$ & $\begin{array}{c}0.314 \\
(0.234) \\
\end{array}$ & $\begin{array}{c}0.100 \\
(0.250) \\
\end{array}$ & $\begin{array}{c}0.223 \\
(0.267) \\
\end{array}$ \\
\hline $\begin{array}{c}\text { Observed } \\
\text { Value }\end{array}$ & 560 & 560 & 560 & 560 & 560 & 560 & 560 \\
\hline Accurate $\mathrm{R}^{2}$ & 0.5481 & 0.5340 & 0.5285 & 0.5253 & 0.5302 & 0.5415 & 0.5695 \\
\hline
\end{tabular}

Notes: (1) $* * *, * *, *$ refers to the significance at the level of $1 \%, 5 \%$, and $10 \%$ respectively; (2) data within the bracket is the standard error.

Besides, if degrees of the specific influences are considered, then the various effects of human capital will be distinctly different with the improvement of the economic growth rate. As is shown in Graph 1 and Graph 2 below, by comparing the quantiles of various human capital effect, the aggregate effect, direct effect and indirect effect of human capital decrease with the increase of quantiles, specifically speaking, from 0.072 down to 0.026 , from 0.098 down to 0.0744 and from -0.027 down to -0.048 respectively. And the complementary effect and adsorption effect of human capital follow the similar law, dropping from 0.0756 to 0.0476 and from -0.1026 to -0.096 respectively, but the latter 
only decreased a little. The graphs have also shown that the direct effects of human capital far exceed its indirect effects and the complementary effects also exceed the absorption effects. What has been analyzed above also shown that the various human capital effects in regions of high growth rate are smaller than those in regions of low growth rate and the main way in which human capital promotes the improvement of economic growth rate is through the direct effects lead by innovation effects. And the conclusions above also further verify the conclusion that in different regional level, the human capital effects are different and the growth rate in Easternregions are generally higher than non-Easternregions, but the aggregate effects of its human capital are lower than non-Easternregions.

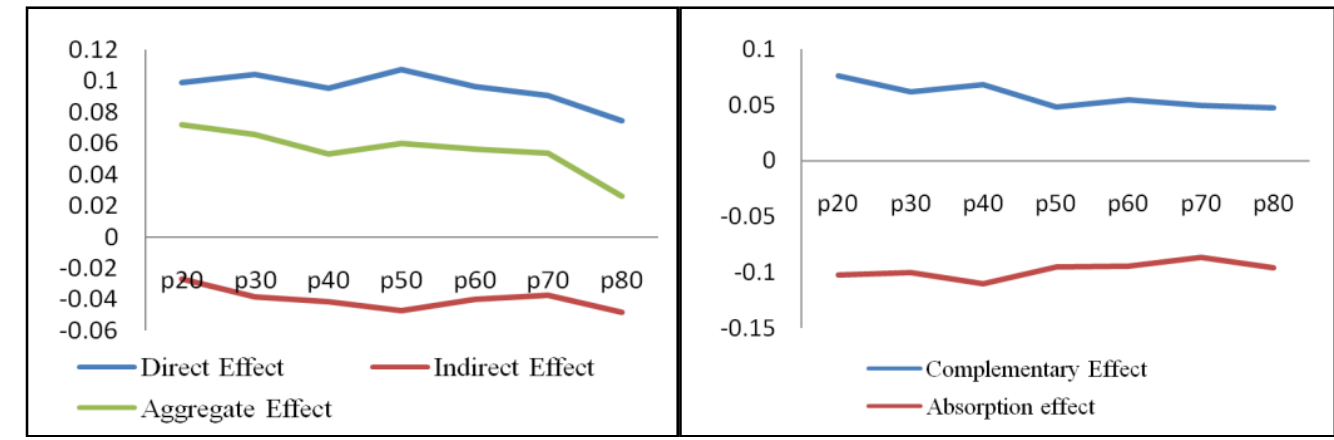

\section{Graph 1 The Aggregate Effect of Human Capital and Effects Specification} Graph 2 The complementary effect and absorption effect of human capital

\section{Conclusions}

This thesis choose the 28 provinces, cities and autonomous regions across the country from 1990 to 2014 as the research sample and test the direct effects and indirect effects of human capital nationwide and in different regional level based on the FGLS estimation multiplicative interaction terms two-way fixed effect panel model. And we can find that, (1) after a comprehensive consideration of the output effect, complementary effect, innovation effect and absorption effect of human capital, the new estimation finds that the aggregate effect of human capital on economic growth rate has improved a lot compared with previous studies, but the dominant role of the physical capital investment still cannot be shaken. (2) The various effects of human capital will differ in the regional level due to the difference in geological position and policy, and the aggregate effect and various effects of human capital in Eastern regions are all smaller than those in non-Eastern regions and the non-Eastern regions can be further divided. In terms of direct effects, the direct effects of human capital in Easternregions are evidently smaller than those in Middle and Western regions, while bigger than those in Northeasternregions. (3) Various effects of human capital also demonstrate different features due to the different geological position and the direct effects and indirect effects of human capital in coastal regions are all smaller than those in inland regions. (4) The aggregate effect and its various effects of human capital all decrease with the increase of the economic growth rate. (5) There exists evident conditional convergence no matter across the nation or in various regional levels, and the methods of economic growth are all driven by the investment of physical capital. The domestic technology spillover effect has distinctly regional features.

\section{Acknowledgement}

Appreciation also goes to the Research Center of Circular Economy Development of Hubei Province in China (Grant No. HXFKY1512) and the Doctoral Research Start-up Fund of Hubei University of Technology (Grant No. BSQD14059) for their support of this research. 


\section{References}

[1] Nelson, R., Technology, institutions and economic growth. Cambridge: Harvard University Press, 2005.

[2] Benhabib, J. and Spiegel, M., The role of human capital in economic development: Evidence from aggregate cross-country data. Journal of Monetary Economics, 1994, 34(2): 143-174.

[3] Dowrick, S., Ideas and education: level or growth effects?NBER Working Paper, 2003.

[4] Chun-ChienKuo, Chih-Hai Yang, Knowledge capital and spillover on regional economic growh: Evidence from China. China Economic Review,2008, 19(4):594-604.

[5] Zhang, Q. J. and Sun, Y. Y. Technology Spillover of Import Trade, Spatial Diffusion of Technology and Regional Technology Gap. South China Journal of Economics, 2011, (10): 146-161.

[6] Zhang, J. Q. and Zhang, Y. H. Are the Aggregate Effects of China's Human Capital Underestimated? Chinese Population, Resources and Environment, 2014, (7): 114-122.

[7] Griliches, Z. Capital-skill complementarity. Review of Economics and Statistics, 1969, 51(4), 465-468

[8] Pritchett L., Where Has All the Education Gone?World Bank Economic Review.2001, (15): 367—391.

[9] Klenow, Peter J., and Andrés Rodriguez-Clare, The Neoclassical Revival in Growth Economics: Has It Gone Too Far?NBER. Macroeconomics Annual, 1997, 73-103.

[10] Gary S. B., Human capital: A theoretical and empirical analysis, with special reference to education. Chicago: University of Chicago Press, 1964.

[11] Aghion, P., and P. Howitt., Endogenous Growth Theory. London: MIT Press, 1998.

[12] Lucas Robert, "On the Mechanics of Economic Development". Journal of Monetary Economics, 1988, (22):3-42.

[13] Romer, P., Endogenous Technological Change. Journal of Political Economy, 1990, (98): 71 - 102.

[14] Bils,Mark, and Peter J. Klenow, Does Schooling Cause Growth? Economic Review, 2000,90(5): 1160-83.

[15] Schumpeter, J. theory of economic development. Boston: Harvard University Press, 1934.

[16] Nelson, R. and Phelps, E., Investment in humans, technology diffusion and economic growth, American Economic Review, Papers and Proceedings, 1966, 56 (2): 69-75.

[17] Benhabib, J. and Spiegel, M., Human capital and technology diffusion, Handbook of economic growth. 1A, 2005, 935-966.

[18] Kelle, Wolfgang, Absorptive Capacity: On the Creation and Acquisition of Technology in Development. Journl of Development Economics, 1996, (49): 199-227.

[19] Xu, Bin, Multinational Enterprises, Technology Diffusion, and Host Country Productivity Growth. Journal of Development Economics, 2000, 62(2): 477-493.

[20] Acharya, R. C., and W. Keller, Technology Transfer through Imports. Canadian Journal of Economics, 2009, 42(4): 1411-1448.

[21] Berman, E., Somanathan, R., and Tan, H. W., Is skill-biased technology change here yet? Evidence from Indian manufacturing in the 1990s. World Bank Policy Research working paper.2005.

[22] Zhang, F. Estimation of China's Physical Capital and Human Capital. Economic Research Journal, 2000,(8):65-71.

[23] Yan Wang and Yudong Yao,sources of china's economic growth 1952-1999.China Economic Review,2003,(14):32-52.

[24] Bian, Y. J. and Shen, L. S. Empirical Analysis of the Influences of Human Capital on the EasternandWestern Economic Growth of China. The Journal of Quantitative and Technical Economics, 2004,(14):19-24.

[25] Chen, Z., Lu, M., and Jin, Y. Regional Differences of China's Human Capital and Educational Development: Estimation for Panel Data. The Journal of World Economy, 2004,(12):25-77.

[26] Yao, X. G., and Zhang, H. F. Education, Human Capital and Regional Economic Differences. Economic Research Journal, 2008,(5):47-57.

[27] Wei CHI,the role of human capital in china's economic development reivew and new evidence, China Economic Review, 2008,(19):421-436.

[28] Lai, M. Y., Zhang, X., Peng, S. J., and Bao, Q. Source of Economic Growth, Human Capital, Research and Development and Technology Spillover. Social Sciences in China, 2005,(2):32-46.

[29] Xie, J. G., and Zhou, L. Z. Import Trade, Absorptive Capacity and International R\&D Technology Spillover: Research on the Panel Data of Chinese Provinces and Regions. The Journal of World Economy, 2009,(9):68-81.

[30] Zhang, J. Q., and Sun, Y. Y. Comparative Study of Import Trade and FDI Technology Spillover Empirical Test based on the Endogeneity of Technology Spillover. World Economy Study, 2011,(12):51-58.

[31] Shu, Y. and Cai, G. W. Analysis of the Inter-provincial Technology Progress and its Spatial Diffusion in China. Economic Research Journal, 2007,(6):106-118.

[32] Comin.D.and B.Hobijn,Lobbies and Technology Diffusion,Review of Economics and Statistics, 2009,91(2):229-244.

[33] Coe, D. T. and E.Helpman and A. W.Hoffmaister,International R\&D Spillovers and Institutions, European Economic Review,2009,53(7):723-741.

[34] Coe,D.T.and Helpman, E. International R\&D spillovers, European Economic Review,1995,39(5):859- 
887.

[35] Fleisher.B,Haizheng Li and Min Qiang Zhao,Human capital,economic growth,and regional inequality in China,Journal of Development Economics,2010,(92):215-231.

[36] Zhang, J., Wu, G. Y. and Zhang, J. P. Estimation of the Physical Capital Stock in the Provincial Level of China: 1952-2000. Economic Research Journal, 2004,(10):35-44.

[37] Yue, S. J. and Liu, C. M. Analysis of Human Capital and Regional Total Factor Productivity. Economic Research Journal, 2006,(4):90-96.

[38] Klenow,Peter J.,and Andrés Rodriguez-Clare,The Neoclassical Revival in Growth Economics:Has It Gone Too Far?NBER Macroeconomics Annual,1997,73-103.

[39] LeSage,J.,and R,Pace,Introduction to Spatial Econometrics.Boca Ration:Chapman \& Hall/CRC,Taylor \& Francis Group,2009. 